\title{
Christus Jesus, die Krag van God en die Wysheid van God
}

\begin{abstract}
Book Title:
Matthew's portraits of Jesus. Six studies in Matthew

Book cover:

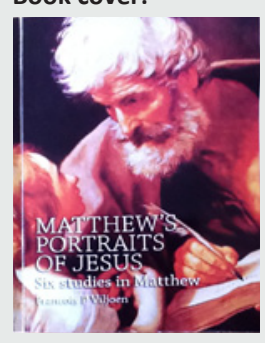

Author:

F.P. Viljoen

ISBN:

978-0-86955-192-5

Publisher:

Potchefstroomse Teologiese Publikasies (Potchefstroom), 2011

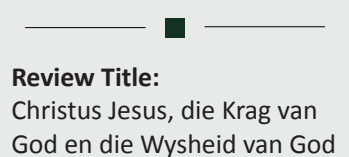

Reviewer:

H. Dijkstra

\section{Affiliation:}

Reformed Church,

Groblersdal, South Africa

Email:

0825660411@vodamail.co.za

Postal address:

PO Box 20311, Noordbrug

2522, South Africa
\end{abstract}

How to cite this book review: Dijkstra, H., 2012, 'Christus Jesus, die Krag van God en die Wysheid van God', Koers - Bulletin for Christian Scholarship 77(2), Art. \#344, 2 pages. http://dx.doi. org/10.4102/koers.v77i2.344

C 2012. The Authors. Licensee: AOSIS OpenJournals. This work is licensed under the Creative Commons Attribution License.
Hierdie publikasie is die resultaat van professor Viljoen se voortgesette navorsing oor die evangelie volgens Matteus. Dit volg op 'n vorige publikasie in 2009: Studies in Matthew. Die oorhoofse titel van die boek (Matthew's portraits of Jesus) is dieselfde as dié van die tema van die eerste van die ses studies in die evangelie. In die verskillende studies word die leser 'n getuie van hoe 'n skildery-in-wording van Jesus algaande duideliker en vollediger herkenbaar word.

Die ses temas is die volgende:

- Hoe Jesus in die evangelie van Matteus geteken word, nie bloot op grond van sy titels (soos byvoorbeeld Christus, Seun van Dawid, Seun van Abraham, Immanuel, Koning, Here, Seun van die mens, Seun van God, Leermeester) as sodanig nie, maar hoe hierdie titels in die breë konteks en bedoeling van die evangelieverhaal en in aansluiting met Ou-Testamentiese motiewe ingekleur word.

- Die verskynings van 'n engel van die Here in die eerste hoofstukke van die evangelie. In die konteks van destydse opvattings val die verskynsel van die ster van Betlehem, volgens die outeur, ook onder hierdie verskynings. Hierdie studie kan as 'n voortsetting van 'n studie in die eerste bundel oor die betekenis van drome en die ster in die evangelie beskou word.

- Gesag en mag in die evangelie van Matteus. Ondanks die oënskynlik onbeperkte mag van die Romeinse gesagsdraers van daardie tyd, toon die skrywer aan dat die Koning van die koninkryk van God in werklikheid regeer.

- Die verklaring van Visio Dei in Matteus 5:8 bied 'n fassinerende, veelkleurige verklaringsgeskiedenis van hierdie teks soos dit deur die ideologiese en teologiese oortuigings van onderskeie verklaarders beïnvloed is. Uit die Joodse, Grieks-Romeinse en Christelike verklaringsmateriaal wat aangebied word, word dit duidelik dat die Skrifteks nie eenvoudig in isolasie verstaan kan word nie, maar dat die voorgeskiedenis, kontemporêre en postgeskiedenis daarvan medebepalend is.

- Matteus 6:22-23 (die lamp van die liggaam is die oog) in konteks verklaar. Hierdie verklaring lewer 'n verrassende resultaat, naamlik dat die moderne wyse waarop met die begrip 'visie' gewerk word, 'n na-binne-gekeerde siening is: die oog as venster van die liggaam. Die opvatting van 'visie' in die destydse konteks is egter presies die teenoorgestelde: die strale van die oog wat na buite gerig is! In etiese terme verklaar, is 'visie' dan ' $n$ funksie van die morele lig of duisternis in 'n persoon wat deur die kanaal van die oog na buite geopenbaar word. Die teksuitspraak het dus nie bloot betrekking op die karakter van 'n persoon nie, maar veral op die optredes wat die resultaat is van die karakter van die persoon.

- Die kontroversie tussen Jesus en die Fariseërs oor die sabbat in Matteus 12:1-8 en 12:9-14 word in samehang met Matteus 5:17-20 (Jesus se verklaring oor die wet), 11:25-30 en 12:15-21 verklaar. Die ware betekenis van die Sabbatsgebod word in Jesus vervul: In Hom kry die gebod sy volle betekenis. In hierdie studie word die tema oor Jesus se onderrig in die bergrede oor die wet, wat in die skrywer se vorige bundel bespreek is, verder uitgewerk.

Verskeie Nuwe-Testamentiese vakkundiges beoordeel hierdie publikasie as van hoogstaande akademiese waarde en is van mening dat dit 'n belangrike bydrae tot die navorsing oor die evangelie van Matteus lewer.

In die studies word ruimskoots verwys na die tersaaklike jongste vakliteratuur. Die literatuur word deurgaans krities evalueer, nie aan die hand van ' $n$ by voorbaat aanvaarde geheelbeskouing nie, maar aan die hand van 'n gedetailleerde eksegese, waarin die hermeneutiese reëls van Skrifverklaring op gebalanseerde wyse tot uitdrukking kom. Dit is veral opvallend dat die skrywer voortdurend ' $n$ teks in wyer Skrifverband en in die konteks van die tyd waarin die evangelie ontstaan het, plaas. Om hierdie redes is die weg waarlangs daar stap vir stap konklusies bereik word, myns insiens oortuigend.

Hierdie publikasie teiken in die eerste plek akademici en studente in die Nuwe-Testamentiese vakwetenskappe, maar aangesien die studies helder geformuleer en beredeneer is, is dit ook 
toeganklik vir'n breër godsdienstige of kerklike publiek, veral vir predikante. Die studies dui aan hoe onverantwoordelik en gevaarlik dit is om ' $n$ Skrifteks bloot op sigwaarde en met die eerste oogopslag te verklaar.

Die gebruik van Grieks in die studies is van so 'n aard dat kennis van hierdie taal nie noodsaaklik is vir die vrugbare gebruik van die boek deur persone wat ernstig Bybelstudie doen nie.

Die skrywer se uitgangspunt ten opsigte van Skrifbeskouing kom in die studies implisiet, en nie hinderlik eksplisiet nie, tot uitdrukking, sodat geen wetenskaplik of andersins geïnteresseerde leser by voorbaat beïnvloed of uitgesluit word nie.
In aansluiting by die titel van die boek sou ek as 'n geskikte opskrif aanbeveel: "n Skildery van Jesus in wording'. Die redes vir hierdie aanbeveling is in die eerste plek die feit dat die skrywer self die studies aanbied as 'voortgaande ondersoek', en in die tweede plek die feit dat daar in die studies nie met 'n vooraf-vasgestelde eenheidskonsep nie, maar met gedetailleerde eksegese gewerk word. Die sistematiese opbou van die studies dra gevolglik nie die negatiewe kenmerk van 'n sisteem waarvan die eindresultaat by voorbaat vasstaan nie.

\section{Slot}

Ek wil hierdie studies van harte aanbeveel soos wat dit aangebied word, as ' $n$ voortgesette ondersoek in die evangelie van Matteus. 